\title{
Preterm Birth: An Inflammatory Syndrome, Not Just A Myometrial Disorder
}

\author{
Thuy-An Mai-Vo¹, Mathieu Nadeau-Vallée ${ }^{1,2,3}$, Alexandra Beaudry-Richard ${ }^{3,4}$ \\ ${ }^{1}$ Faculty of Medicine, Université de Montréal \\ ${ }^{2}$ Department of Pharmacology, Université de Montréal \\ ${ }^{3}$ Departments of Pediatrics, Ophthalmology and Pharmacology, CHU Sainte-Justine Research Center
}

\section{ABSTRACT}

Preterm birth (PTB) is the leading cause of neonatal mortality and morbidity. Although the severity of neonatal outcomes is inversely correlated with gestational age, all PTBs can lead to potentially life-threatening neonatal outcomes and major lifelong health complications. Because advances in neonatal care have substantially decreased neonatal mortality, the incidence of PTB and its complications is unabatedly rising. PTB currently affects more than $10 \%$ of births worldwide, with similar numbers in developed countries. Correspondingly, improving neonatal outcome is a key objective of the World Health Organization. The recently approved (in Europe) tocolytics drug, Atosiban, used to prolong preterm gestation, has not been shown to improve neonatal outcome, nor have other tocolytic agents used in clinic. Thus, PTB remains an unmet medical need. Recent evidence shows that most, if not all, PTBs are associated with (overt or occult) inflammatory processes in gestational tissues, independent of infection. Proinflammatory cytokines are produced from maternal and fetal cells in response to sterile or infectious stressors. These seem to orchestrate a multi-tissue response including myometrial contractility, cervical ripening, and weakening/rupture of fetal membranes, leading to the onset of preterm labor. This integrated system might have been conserved through mammalian evolution due to increased maternal and/or fetal survival when gestation is terminated in specific settings, such as infection. Hence, inflammation may be a common pathway to the numerous aetiologies of PTB. Most importantly, recent evidence suggests that inflammation is transmitted to the fetus, thereby inducing organ injuries that may underlie the development of major neonatal diseases. Targeting inflammation prenatally instead of myometrial contraction could be a more successful and safe approach for the management of PTB, as suggested by recent animal studies.

\section{RÉSUMÉ}

La naissance prématurée est la principale cause de mortalité et de morbidité néonatale. Bien que la sévérité des issus néonataux soit inversement corrélée avec l'âge gestationnel à la naissance, toutes les naissances prématurées peuvent mener à des issus néonataux potentiellement mortels et à des complications avec répercussions s'échelonnant sur toute la vie. Étant donné que la mortalité néonatale a considérablement diminuée avec les récentes avancées en néonatalogie, l'incidence de la naissance prématurée et de ses complications sont en hausse. La naissance prématurée affecte présentement plus de 10\% des naissances à travers le monde, avec des taux similaires dans les pays développés. Conséquemment, d'améliorer l'issu néonatal est un objectif clé de l'Organisation Mondiale de la Santé. Le tocolytique Atosiban récemment approuvé (en Europe) pour prolonger les gestations prématurées n'a pas démontré d'efficacité pour améliorer les issus néonataux, tout comme les autres tocolytiques utilisés en clinique, et la naissance prématurée demeure un besoin médical non-atteint. Des données récentes démontrent que la plupart, sinon toutes les naissances prématurées sont associées avec des processus inflammatoires (francs ou silencieux) dans les tissus gestationnels, indépendamment de l'infection. Les cytokines pro-inflammatoires sont produites dans les cellules maternelles et fotales en réponse à des stresseurs stériles ou infectieux, et semblent orchestrer une réponse multi-tissulaire incluant la contractilité myométriale, la préparation cervicale, et l'affaiblissement/rupture des membranes fotales, menant au commencement du travail préterme. Ce système intégré pourrait avoir été conservé durant l'évolution mammifère à cause d'une survie accrue de la mère et/ou du fœtus lorsque la gestation est terminée dans un contexte spécifique, comme l'infection. Donc, l'inflammation pourrait constituer une voie commune finale pour les nombreuses causes de la naissance prématurée. De façon importante, des données récentes suggèrent que cette inflammation est transmise au fœetus et en retour induit des dommages aux organes qui pourraient sous-tendre le développement de maladies néonatales majeures. De cibler l'inflammation en prénatal plutôt que les contractions myométriales pourrait constituer une approche sécuritaire et plus efficace, comme suggéré par de récentes études animales.

Keywords: Preterm birth; Tocolytics; Neonatal morbidity; Inflammation; Chorioamnionitis; Interleukin-1 
$\mathbf{E}$ ach year, approximately 15 million babies worldwide (more than one in 10 births) are born preterm ( $<37$ weeks of gestation) [1,2]. Preterm birth (PTB) rates are increasing in most countries, with the highest reported in the USA, Africa and Southeast Asia [1]. Prematurity is currently the leading cause of neonatal mortality and the second most frequent cause of death after pneumonia among children under 5 years old [3]. Thus, the global burden of PTB on maternal and child health calls for an urgent need to develop effective preventive and treatment strategies to reduce the incidence of PTB.

PTB can be medically indicated (iatrogenic) or spontaneous. In high income countries, about one third of pregnancies are interrupted for maternal or fetal indications, such as preeclampsia and diabetes $[4,5]$. About $70 \%$ of PTBs follow spontaneous labor, with membranes either intact or prematurely ruptured. PTBs can also be subdivided based on gestational age, into extreme preterm ( $<28$ weeks, accounting for $5 \%)$, severe preterm (28-31 weeks, 20\%), moderate preterm (32-33 weeks, 20\%) and late preterm (34-36 weeks, 60-70\%] [5].

PTB is now viewed as a complex syndrome arising from multiple mechanisms, such as inflammation or infection, uteroplacental ischemia or hemorrhage, uterine overdistension and stress [2]. Several maternal or fetal risk factors have been linked to PTB. Maternal characteristics include previous preterm deliveries, multiple gestation, extremes in maternal age and BMI, race, and low socioeconomic and educational status. Nutritional status during pregnancy may also affect birth outcomes [2]. Common fetal conditions associated with PTB birth are smallfor-gestational-age birth, fetal distress and congenital malformations [6].

Preterm infants are delivered at a time when organ development is still ongoing. Ensuing immaturity of many organ systems at birth put newborns at a greater risk of neonatal complications, most commonly bronchopulmonary dysplasia, necrotizing enterocolitis, periventricular leukomalacia and retinopathy of prematurity [7]. Inflammation and oxidative stress have been proposed as major contributors to these diseases [8]. The current pharmacological approach for PTB aims at prolonging gestation to gain enough time for administration of corticosteroids for lung maturation. However, simply prolonging gestation has shown no improvement in short- and long-term neonatal outcome. Although major advances in perinatal care over the last few decades have improved the survival of preterm babies, recent epidemiological studies show an increased risk of chronic disorders in adulthood following PTB, including hypertension, diabetes and obesity [5]. Clearly, treating PTB as a myometrial disorder has not been effective. A wide body of evidence indicates that in utero inflammation is present in most PTB, especially extreme and severe PTB, independent of infection [9]. Most importantly, maternal in utero inflammation can reach the fetus and induce a fetal inflammatory response syndrome [10], with major implications for neonatal outcomes. Therefore, an emerging paradigm in preclinical research is to target cytokines and other inflammatory factors that are implicated in both PTB and fetal/neonatal organ injuries, using prenatal delivery of candidate drugs.

This review will summarize the candidate drugs used to prolong gestation in case of spontaneous PTB, and review the recent data on the role of inflammation and anti-inflammatory drug candidates in PTB and associated neonatal complications.

\section{PHARMACOLOGICAL APPROCHES IN THE TREATMENT OF PTB}

Most therapeutic agents for PTB are designed to target the myometrium in order to arrest or delay labor in symptomatic (laboring) women. These agents are referred to as tocolytics (from the Greek tokos, childbirth; and lytic, dissolving) and represent the mainstay of treatment to prolong gestation in order to gain sufficient time for administration of corticosteroids (to accelerate lung maturation and surfactant production) or transport to a tertiary care unit. Because tocolytics have numerous side effects and have not been shown to improve neonatal outcome, some clinicians prefer not to use them, especially in case of late PTB. The first clinical trials of tocolytics began in the late 1960s and 1970s [11]. Since then, numerous tocolytic candidates have been used, most of them off-label (e.g. indomethacin). Out of all the therapeutic molecules employed to prolong gestation, only progesterone has been used in asymptomatic (non-laboring) women at risk of PTB. Progesterone and the most used tocolytics will be reviewed in this section.

\section{Ritodrine}

Numerous $\beta$-mimetics have been used as tocolytics (e.g. terbutaline, ritodrine, salbutamol), but the most used is ritodrine [11]. $\beta$-mimetics bind and activate $\beta$-adrenergic receptors on myometrial cells. $\beta$-adrenergic receptors are Gs protein-coupled receptors and therefore activate adenylyl cyclase-induced production of $\mathrm{AMPc}$, in turn reducing intracellular $\mathrm{Ca}++$ levels 
Table 1. Most used therapeutic molecules for the treatment and prevention of PTB.

\begin{tabular}{|c|c|c|c|c|}
\hline $\begin{array}{l}\text { Therapeutic } \\
\text { agents }\end{array}$ & $\begin{array}{c}\text { Mechanism of } \\
\text { action }\end{array}$ & Efficacy & Adverse effect profile & $\begin{array}{c}\text { RCTs }^{a} \text { and } \\
\text { meta- } \\
\text { analysis }\end{array}$ \\
\hline Ritodrine & $\begin{array}{l}\beta_{2} \text {-adrenergic } \\
\text { agonist: } \\
\uparrow \text { CAMP }\left(\mathrm{G}_{\mathrm{s}}\right) ; \\
\downarrow \text { intracellular } \mathrm{Ca}^{+} \\
\ddagger \\
\downarrow \text { MLCK activation } \\
\text { in myocytes }\end{array}$ & $\begin{array}{l}\text { - Prolong gestation } \\
\text { for } 48 \mathrm{~h} \text { vs placebo } \\
\text { - Elicits no } \\
\text { improvement of } \\
\text { perinatal outcome }\end{array}$ & $\begin{array}{l}\text { High frequency of } \\
\text { potentially life- } \\
\text { threatening maternal } \\
\text { and fetal side effects } \\
\text { including: palpitations, } \\
\text { tremor, nausea, } \\
\text { headaches, and chest } \\
\text { pain [72]. }\end{array}$ & [12] \\
\hline Nifedipine & $\begin{array}{l}\text { Calcium channel } \\
\text { blocker }\end{array}$ & $\begin{array}{l}\text { - More effective } \\
\text { than ritodrine to } \\
\text { prolong gestation } \\
\text { - Decreases rates } \\
\text { of severe neonatal } \\
\text { morbidity }\end{array}$ & $\begin{array}{l}\text { Fewer maternal side } \\
\text { effects than ritodrine. } \\
\text { Includes: flushing, } \\
\text { headache, dizziness, } \\
\text { nausea and transient } \\
\text { hypotension. Possible } \\
\text { neonatal side effects } \\
\text { include: tachycardia, } \\
\text { hypoglycemia and } \\
\text { hypocalcemia. }\end{array}$ & {$[14,15]$} \\
\hline Atosiban & $\begin{array}{l}\text { Oxytocin receptor } \\
\text { antagonist }\end{array}$ & $\begin{array}{l}\text { As effective as } \\
\text { ritodrine to prolong } \\
\text { gestation }\end{array}$ & $\begin{array}{l}\text { Lower side-effect profile } \\
\text { than ritodrine and most } \\
\text { tocolytics. }\end{array}$ & [20] \\
\hline $\begin{array}{l}\text { Magnesium } \\
\text { sulphate }\end{array}$ & $\begin{array}{l}\text { Competes with } \\
\mathrm{Ca}^{++} \text {for entry into } \\
\text { the cell; } \\
\text { Blocks } \\
\text { calmodulin- } \\
\text { induced activation } \\
\text { of MLCK }\end{array}$ & $\begin{array}{l}\text { Not more effective } \\
\text { than placebo }\end{array}$ & $\begin{array}{l}\text { Lower side-effect profile } \\
\text { than most other } \\
\text { tocolytic agents. }\end{array}$ & [18] \\
\hline Indomethacin & $\begin{array}{l}\text { COX-2 inhibitor: } \\
\downarrow \mathrm{PGF}_{2 \mathrm{a}} \\
\downarrow \mathrm{PGE}_{2}\end{array}$ & $\begin{array}{l}\text { Insufficient level of } \\
\text { evidence for firm } \\
\text { conclusions }\end{array}$ & $\begin{array}{l}\text { Major side effects on } \\
\text { fetal kidney } \\
\text { development and } \\
\text { cardiovascular system }\end{array}$ & [25] \\
\hline $\begin{array}{l}\text { Vaginal } \\
\text { progesterone } \\
\text { prophylaxis }\end{array}$ & $\begin{array}{l}\text { Promotes uterine } \\
\text { quiescence }\end{array}$ & $\begin{array}{l}\text { Insufficient level of } \\
\text { evidence for firm } \\
\text { conclusions }\end{array}$ & $\begin{array}{l}\text { Lower side-effect profile } \\
\text { than most tocolytic } \\
\text { agents. }\end{array}$ & {$[28,29]$} \\
\hline $\begin{array}{l}17 a- \\
\text { hydroxyprogester } \\
\text { one caproate } \\
\text { prophylaxis } \\
\text { [synthetic } \\
\text { progestin] }\end{array}$ & $\begin{array}{l}\text { Promotes uterine } \\
\text { quiescence }\end{array}$ & $\begin{array}{l}\text { Insufficient level of } \\
\text { evidence for firm } \\
\text { conclusions }\end{array}$ & $\begin{array}{l}\text { Lower side-effect profile } \\
\text { than most tocolytic } \\
\text { agents. Its use has } \\
\text { been associated with } \\
\text { increased incidence of } \\
\text { gestational diabetes }\end{array}$ & [73] \\
\hline
\end{tabular}

aRCT: randomized control trials. 
Table 2. Anti-inflammatory agents in preclinical testing for the prevention of PTB.

\begin{tabular}{|l|l|l|l|}
\hline Therapeutic agent & Inflammatory target & \multicolumn{1}{|c|}{ Mechanism of action } & Reference \\
\hline Resveratrol & Macrophage & $\begin{array}{l}\text { Activates sirtuin-1 and NAD+-dependant } \\
\text { deacetylase }\end{array}$ & {$[74-77]$} \\
\hline Tregs & T-cells & Regulates inflammatory cells & {$[78]$} \\
\hline 15 -epi-lipoxin A4 & Neutrophils & $\begin{array}{l}\text { Modulates leukotrienes derived from } \\
\text { arachidonic acid }\end{array}$ & {$[65]$} \\
\hline Anakinra & IL-1 receptor & Competitively inhibits the receptor & {$[28,61]$} \\
\hline 101.10 & IL-1 receptor & Non-competitively inhibits the receptor & {$[62,68]$} \\
\hline
\end{tabular}

and promoting the inactivation of myosin light-chain kinases (MLCK; a group of enzymes important for contraction) in myometrial smooth muscle cells [11].

Several randomized control trials (RCTs) and meta-analyses concur to the efficacy of ritodrine to prolong gestation by at least $48 \mathrm{~h}[12,13]$. However, there is no evidence for improvement of neonatal outcomes [12]. The current rationale for using ritodrine (and other tocolytics) is to gain enough time for corticosteroid action to kick in and transfer to a tertiary care facility. However, ritodrine (and other $\beta$-mimetics) also interact with cells other than myometrial tissue, resulting in maternal and fetal adverse effects (see Table 1). Since other similarly effective tocolytics have been shown to cause less significant side effects, ritodrine is no longer marketed in the USA [11].

\section{Nifedipine}

Calcium is an essential signal transducer of pro-contractile intracellular targets by binding to and activating calmodulin. The resulting complex activates MLCK, in turn promoting actomyosin interaction and contraction. Nifedipine blocks calcium channels, thereby reducing intracellular calcium levels and reducing actomyosin activity in smooth muscle cells. A meta-analysis published in 2002 showed that if calcium channel blockers were administered before 34 weeks of gestation, they could prolong gestation by 7 days [14]. This is a much longer period of time than is provided by $\beta$-mimetics. Calcium channel blockers, specifically nifedipine, have also been shown to have fewer side effects and a lower neonatal morbidity rate [15]. However, nifedipine is associated with higher rates of adverse effects in women with cardiovascular disease, congenital cardiac malformations or pulmonary hypertension $[15,16]$.
Atosiban

Atosiban is the first drug to be developed for preterm labor (as opposed to already existing drugs used off-label) and is largely used in Europe. It is the first member of a new class of tocolytics, the oxytocin receptor antagonists. When oxytocin binds to its receptor in the myometrium, it activates the phospholipase $\mathrm{C} /$ inositol 1,4,5-trisphosphate pathway, leading to the release of intracellular calcium which causes contractions. Atosiban inhibits this pathway, thereby preventing myometrial contractions [17].

In a large multi-centre RCT, atosiban was found to be as effective as $\beta$-mimetics in prolonging gestation, with fewer side effects than $\beta$-mimetics [18]. However, in a large placebo-controlled RCT in the USA, numerous hurdles were encountered. Most significantly, there was bias distribution of pregnant women in the two treatment groups, leading to a significantly higher number of women at low gestational age ( $<26$ weeks) being placed in the atosiban group. In this subgroup, the mortality was significantly higher than in those treated with $\beta$-mimetics. However, in the subgroup that delivered $>28$ weeks, atosiban was more effective than placebo to prolong gestation [19]. Because the data of women that delivered $<26$ weeks were inconclusive and other reasons, FDA has not yet approved the use of atosiban. Atosiban is currently the most used tocolytics drug in Europe, however [11]. Numerous new oxytocin receptor antagonists are being considered for acute tocolysis (e.g. barusiban).

\section{Magnesium sulfate}

Magnesium is a divalent cation that competes with $\mathrm{Ca}++$ for: 1) entry into the cell via calcium channels, and 2) binding to calmodulin (which precedes MLCK activation). Based on this 
rationale, magnesium sulphate is used as a tocolytic agent, but it lost popularity after numerous RCTs and meta-analyses revealed its inefficacy to prolong gestation and an increased risk of fetal and neonatal mortality [20]. Because of the withdrawal of $\beta$-mimetics from the American market and the failure of atosiban to obtain FDA approval, magnesium sulfate has been used extensively in the USA as a first-line tocolytic [11]. Magnesium sulfate is still used antenatally for its neuroprotective effects on the progeny [21]; however, this topic seems to be controversial and possibly depends on different pregnancy settings [22].

Indomethacin

Indomethacin is a non-steroidal, anti-inflammatory drug that reversibly inhibits cyclo-oxygenase 2 (COX-2), thereby inhibiting the production of uterotonic prostaglandins. Indomethacin is widely used in Canada for acute tocolysis. Although it has been shown to prolong gestation [23], its prolonged use ( $>48 \mathrm{~h}$ ) has been associated with severe neonatal complications, including premature closure of ductus arteriosus, renal toxicity, necrotizing enterocolitis, intraventricular hemorrhage, and periventricular leukomalacia [24] . It therefore must be used with utmost caution. There is currently no evidence that indomethacin has any advantage as a first-line tocolytic over calcium channel blockers or oxytocin antagonists, each of which have better side effect profile [25].

\section{Progesterone}

Progesterone maintains uterine quiescence in numerous species. In humans, it is thought to do so by inhibiting inflammation-induced activation of the uterus (as discussed in the next section). Prophylactic use of progesterone in women at risk of PTB appears to have few, if any, side effects. However, its efficacy is controversial. In 2003, two RCTs reported that the use of daily vaginal progesterone administered between week 24 and 33 in high-risk pregnant women [26] or of daily 17a-hydroxyprogesterone caproate (slightly different pharmacological properties) administered between week 16 and 36 [27] decreased the rate of preterm deliveries. However, a recent multi-centre, placebo-controlled, double-blind RCT found no significant difference between vaginal progesterone prophylaxis and placebo in decreasing rates of PTB or improving outcomes at 2 years of age [28]. Because progesterone is safe and may be effective in some patients, many obstetricians use it as prophylaxis therapy to prevent PTB. However, the use of progesterone as an acute tocolytic was unsuccessful [29].
Summary

Given the large amount of data available and the range of evidence for each specific treatment, choosing the correct agent may be puzzling even for an experienced clinician. In the current state of knowledge, it is probably reasonable to administer a tocolytic agent in order to gain sufficient time for corticosteroids treatment and transfer to tertiary care unit. Calcium channel blockers and oxytocin receptor antagonists appear effective and present a more beneficial side effect profile than other candidates. Progesterone might be effective to prevent the onset of preterm labor in specific populations, and its prophylactic administration is safe. Although the use of these strategies has had some advantages, none of the agents available are associated with significant improvement of neonatal outcome. Hence, there is still room for improvement. Recent research efforts have been directed at preventing preterm birth by targeting earlier and upstream events in the cascade leading to PTB. In the next section, we will discuss how inflammation activates the pregnant uterus weeks to months before preterm labor, and how inflammatory mediators can be targeted to improve neonatal outcomes.

\section{INFLAMMATION IN PRETERM BIRTH}

Inflammation plays a crucial role in the onset of preterm labor and is involved in $>60 \%$ of extreme PTB ( $<28$ weeks of gestation) $[2,30]$. Activation of pro-inflammatory cytokines and chemokines at the maternal/fetal interface is associated with PTB [31] and conversely, suppression of inflammation using different agents prevents PTB in numerous animal models [32]. In murine models (hemochorial placentation akin to humans), the intrauterine inflammatory response has been shown to reach the fetal compartment, possibly though a cytokine chain reaction. This induces severe injuries to the fetal organs that begin in utero and persist into adulthood [16]. The inflammatory response begins with bacteria or stressed cells that induce release of small motives (Pathogen/Danger-Associated Molecular Patterns) that are recognized by Toll-like receptors (TLR; receptors part of the innate immune system) expressed throughout gestational tissues. This leads to the production of pro-inflammatory cytokines and chemokines [33], extravasation of myeloid and lymphoid inflammatory cells (mostly neutrophils and monocytes/macrophages), and eventually, activation of many uterine activation proteins (UAPs). These UAPs promote cervical ripening, fetal membrane weakening, contractions and labor [34-36]. Importantly, data show that this inflammatory response does not resolve with birth [16], which may explain the 
inefficacy of tocolytics at improving neonatal outcomes. Interleukin (IL)-1 $\beta$ is a key pro-inflammatory cytokine that has been strongly linked to PTB [37]. Its production is triggered by activation of TLRs via sterile or non-sterile pathways (as mentioned), and it generates a complete inflammatory response (e.g. as seen in the context of an infection) through binding to its ubiquitously expressed receptor IL-1RI. Correspondingly, a single $1 \mu \mathrm{g}$ administration of IL-1 $\beta$ to pregnant mice is sufficient to cause chorioamnionitis and PTB [38]. Other important inflammatory mediators include tumor necrosis factor (TNF)a and IL-6.

Perinatal injuries related to inflammation

Following PTB induced by chorioamnionitis, preterm infants often develop a fetal inflammatory response syndrome (FIRS), exposing many organs to environmental insults and therefore resulting in severe morbidities $[10,30]$. In this section, we will focus on perinatal injuries to organs that are the most vulnerable to inflammation: the lungs, the brain, the gastro-intestinal (GI) tract and the heart.

\section{Lungs}

As the newborn is separated from the maternal womb, its tiny lungs have to take on gas exchange while still in the developing stage. Immaturity of the lungs at birth can lead to respiratory distress syndrome (RDS), a main cause of neonatal mortality and morbidity [39]. Interestingly, many studies show that intrauterine inflammation has a positive impact on RDS, diminishing its incidence by accelerating lung maturation and surfactant production [40-42]. However, chorioamnionitis induces fetal lung inflammation [43] and increases the risk of bronchopulmonary dysplasia, an alveolar and vascular malformation and dysfunction [41]. Resulting decreased lung function often leads to airway obstruction persisting until adulthood, as well as impaired development of other organs due to a lack of oxygen delivery [44].

\section{Brain}

The developing brain in preterm newborns has been shown to be sensitive to inflammatory insults [45]. The white matter is particularly vulnerable to ischemia and injury because of the very low pressure of perfusion [46]. Ischemia and intrauterine inflammation may cause premature differentiation of the oligodendrocytes, thereby increasing vulnerability to fatal insults [47]. Correspondingly, chorioamnionitis predisposes preterm neonates to periventricular leukomalacia [48], periventricular hemorrhagic infarction [49], cerebral palsy [50], and to many other permanent cerebral deficits such as chronic epilepsy and intellectual disability $[45,51]$. Moreover, inflammation and infection are independently linked to neonatal encephalopathy, one of the most prevalent causes of child mortality [52]. Overall, the brain is vulnerable to inflammation, which is a major concern when addressing prematurity and its outcomes.

\section{Gastro-intestinal tract}

Intestinal complications associated with PTB are a major source of admission to the neonatal intensive care unit (NICU) [53]. It was shown in the fetal sheep that IL-1 plays a key role in bowel inflammation by causing damage to the gut mucosae [54]. In the preterm infant, perinatal development of necrotizing enterocolitis and spontaneous intestinal perforation was also linked to inflammation [55].

Heart

Inflammation has also been shown to play a role in in prematurity-related cardiac conditions. Exposing lambs to lipopolysaccharides (LPS, a TLR4 agonist) during gestation caused alterations of the cardiac tissue and function [56]. Some evidence has linked chorioamnionitis and patent ductus arteriosus, a prevalent cardiac defect in preterm newborns, but it is still controversial due to conflicting studies $[57,58]$. Inflammation and prematurity also seem to be involved in the development of arteriosclerosis and cardiovascular disease later in life [59]. Therefore, inflammation may impact fetal heart development, but the exact mechanism by which it does so has yet to be conclusively defined.

\section{CURRENT PRECLINICAL TRIALS TARGETING INFLAMMATION IN PTB}

Given the important role of inflammation in PTB and its consequences on fetal development, modulation of pro-inflammatory mediators has been tested in recent preclinical studies. A short review of the ongoing preclinical advances targeting inflammation in PTB follows (summarized in Table 2).

\section{Resveratrol}

Resveratrol is a natural polyphenol capable of reducing LPSinduced PTB to 36\% (versus $85 \%$ without drug) and stillbirth to $34 \%$ (versus $62 \%$ without drug) when administered orally to pregnant mice [60]. The mechanism of action suggested is downregulation of the expression of pro-inflammatory mediators such as iNOS and COX-2, and suppression of the produc- 
tion of eicosanoids such as prostaglandins. Although promise has been shown in murine models, clinical translation might not give the same results, as many human trials with progesterone have failed to curb PTB $[28,61,62]$.

Tregs

Regulatory $\mathrm{T}$ cells (Tregs) are a subpopulation of CD4+ T cells that downregulate inflammation and play a role in maternal immune tolerance to the fetus [63]. Adoptive transfer of Tregs is a technique where healthy Tregs are transferred to a receiver to alleviate inflammatory syndromes [64]. When tested on a mouse model of PTB induced with LPS, preterm birth was not prevented. However, there was a reduction in pro-inflammatory markers in the fetus's brain, suggesting the use of Tregs may have a protective effect in the context of inflammatory PTB.

\section{Lipoxins}

Arachidonic acid derived leukotrienes have a pro-inflammatory role in stimulating the adhesion and degranulation of neutrophils [65]. Lipoxins are eicosanoids that modulate leukotrienemediated interactions between the endothelium and neutrophils [65]. A recent study showed that when administered during gestation, a lipoxin analogue named 15-epi-lipoxin A4 demonstrated great anti-inflammatory potency [66]. Intra-peritoneal injections during gestation of 15-epi-lipoxin A4 reduced the mortality rate of pups; yet it was inefficient in delaying LPS-induced PTB [67]. Pro-inflammatory markers IL-1 $\beta$, IL-6 and TNFa were not downregulated and the anti-inflammatory cytokine IL-10 was not upregulated, indicating that lipoxins might intervene too far downstream (late) in the inflammatory signaling pathway leading up to preterm labor.

\section{IL-1RI inhibitors}

The pro-inflammatory cytokine IL-1 $\beta$ is a main component of the inflammatory reaction leading to PTB. Therefore, inhibitors of the IL-1RI have been used to try and curb the inflammatory process. The commercially available drug anakinra (Kineret) competitively blocks the receptor and inhibits all of its intracellular pathways [68]. While it does not prevent PTB, it has been proven efficient to protect the fetal brain from inflammatory damage [69]. More recently, a small all-d peptide, 101.10, was designed to partially inhibit IL-1RI without blocking important pathways for cytoprotection [70]. Pre-clinical murine studies have been tremendously promising, as it prevents PTB and protects the fetus from multisystemic perinatal injuries [16,71]. This encouraging finding indicates IL-1 $\beta$ is a good pharmacological target to curb inflammation at the beginning of its cascade, therefore protecting the fetus from inflammation-associated damages.

\section{CONCLUSION}

PTB is a common complication of gestation and represents a major social and economic burden worldwide. Tocolytics can prolong gestation but they have not been shown to improve neonatal outcomes. In clinical settings, preterm neonates are treated postnatally, but most neonatal pathophysiological processes are initiated in utero. New preclinical research points to a promising role of anti-inflammatory agents in improving neonatal outcomes, especially when administered antenatally. Notably, a novel IL-1 antagonist termed 101.10 seems safe and effective in preventing chorioamnionitis-induced perinatal brain, lung, and intestine injuries. In addition to the need of improving existing therapies, further research is warranted to develop specific diagnostic tests and biomarkers to identify women at risk of preterm birth.

\section{REFERENCES}

1. Menon R. Preterm birth: a global burden on maternal and child health. Pathog Glob Health. 2012;106(3):139-40.

2. Goldenberg RL, Culhane JF, lams JD, Romero R. Epidemiology and causes of preterm birth. Lancet. 2008;371(9606):75-84.

3. Beck S, Wojdyla $D$, Say $L$, et al. The worldwide incidence of preterm birth: a systematic review of maternal mortality and morbidity. Bull World Health Organ. 2010;88(1):31-8.

4. Boyle AK, Rinaldi SF, Norman JE, Stock SJ. Preterm birth: Inflammation, fetal injury and treatment strategies. J Reprod Immunol. 2017;119:62-6.

5. Rubens CE, Sadovsky Y, Muglia L, Gravett MG, Lackritz E, Gravett C. Prevention of preterm birth: harnessing science to address the global epidemic. Sci Transl Med. 2014;6(262):262sr5.

6. Ananth $C V$, Vintzileos $A M$. Maternal-fetal conditions necessitating a medical intervention resulting in preterm birth. Am J Obstet Gynecol. 2006;195(6):1557-63.

7. Ward RM, Beachy JC. Neonatal complications following preterm birth BJOG. 2003;110 Suppl 20:8-16.

8. Perrone S, Negro S, Tataranno ML, Buonocore G. Oxidative stress and antioxidant strategies in newborns. J Matern Fetal Neonatal Med. 2010;23 Suppl 3:63-5.

9. Romero R, Dey SK, Fisher SJ. Preterm labor: one syndrome, many causes. Science. 2014;345(6198):760-5.

10. Gotsch F, Romero R, Kusanovic JP, et al. The fetal inflammatory response syndrome. Clin Obstet Gynecol. 2007;50(3):652-83.

11. Olson DM, Christiaens I, Gracie S, Yamamoto Y, Mitchell BF. Emerging tocolytics: challenges in designing and testing drugs to delay preterm delivery and prolong pregnancy. Expert Opin Emerg Drugs. 2008;13(4):695707.

12. Anotayanonth S, Subhedar NV, Garner P, Neilson JP, Harigopal S. Betamimetics for inhibiting preterm labour. Cochrane Database Syst Rev. 2004(4):CD004352.

13. Merkatz IR, Peter JB, Barden TP. Ritodrine hydrochloride: a betamimetic agent for use in preterm labor. II. Evidence of efficacy. Obstet Gynecol. 1980;56(1):7-12

14. King JF, Flenady VJ, Papatsonis DN, Dekker GA, Carbonne B. Calcium 
channel blockers for inhibiting preterm labour. Cochrane Database Syst Rev. 2002(2):CD002255.

15. Flenady V, Wojcieszek AM, Papatsonis DN, et al. Calcium channel blockers for inhibiting preterm labour and birth. Cochrane Database Syst Rev. 2014(6):CD002255.

16. Nadeau-Vallee M, Chin PY, Belarbi L, et al. Antenatal Suppression of IL-1 Protects against Inflammation-Induced Fetal Injury and Improves Neonatal and Developmental Outcomes in Mice. J Immunol. 2017;198(5):2047-62.

17. Akerlund M, Carlsson AM, Melin P, Trojnar J. The effect on the human uterus of two newly developed competitive inhibitors of oxytocin and vasopressin. Acta Obstet Gynecol Scand. 1985;64(6):499-504.

18. Crowther CA, Hiller JE, Doyle LW. Magnesium sulphate for preventing preterm birth in threatened preterm labour. Cochrane Database Syst Rev. 2002(4):CD001060.

19. Romero R, Sibai BM, Sanchez-Ramos L, et al. An oxytocin receptor antagonist (atosiban) in the treatment of preterm labor: a randomized, doubleblind, placebo-controlled trial with tocolytic rescue. Am J Obstet Gynecol. 2000;182(5):1173-83.

20. Worldwide Atosiban versus Beta-agonists Study G. Effectiveness and safety of the oxytocin antagonist atosiban versus beta-adrenergic agonists in the treatment of preterm labour. The Worldwide Atosiban versus Beta-agonists Study Group. BJOG. 2001;108(2):133-42.

21. Jung EJ, Byun JM, Kim YN, et al. Antenatal magnesium sulfate for both tocolysis and fetal neuroprotection in premature rupture of the membranes before 32 weeks' gestation. J Matern Fetal Neonatal Med. 2017:1-11.

22. Edwards JM, Edwards LE, Swamy GK, Grotegut CA. Magnesium sulfate for neuroprotection in the setting of chorioamnionitis. J Matern Fetal Neonatal Med. 2017:1-8.

23. Panter KR, Hannah ME, Amankwah KS, Ohlsson A, Jefferies AL, Farine $D$. The effect of indomethacin tocolysis in preterm labour on perinatal outcome: a randomised placebo-controlled trial. Br J Obstet Gynaecol. 1999;106(5):467-73.

24. Abou-Ghannam G, Usta IM, Nassar AH. Indomethacin in pregnancy: applications and safety. Am J Perinatol. 2012;29(3):175-86.

25. King J, Flenady V, Cole S, Thornton S. Cyclo-oxygenase (COX) inhibitors for treating preterm labour. Cochrane Database Syst Rev. 2005(2):CD001992.

26. da Fonseca EB, Bittar RE, Carvalho MH, Zugaib M. Prophylactic administration of progesterone by vaginal suppository to reduce the incidence of spontaneous preterm birth in women at increased risk: a randomized placebo-controlled double-blind study. Am J Obstet Gynecol. 2003;188(2):41924.

27. Meis PJ, Klebanoff $M$, Thom E, et al. Prevention of recurrent preterm delivery by 17 alpha-hydroxyprogesterone caproate. N Engl J Med. 2003;348(24):2379-85.

28. Norman JE, Marlow N, Messow CM, et al. Vaginal progesterone prophylaxis for preterm birth (the OPPTIMUM study): a multicentre, randomised, double-blind trial. Lancet. 2016;387(10033):2106-16.

29. Martinez de Tejada B, Karolinski A, Ocampo MC, et al. Prevention of preterm delivery with vaginal progesterone in women with preterm labour (4P): randomised double-blind placebo-controlled trial. BJOG. 2015;122(1):8091.

30. Galinsky R, Polglase GR, Hooper SB, Black MJ, Moss TJ. The consequences of chorioamnionitis: preterm birth and effects on development. J Pregnancy. 2013;2013:412831.

31. Bukowski R, Sadovsky $Y$, Goodarzi $H$, et al. Onset of human preterm and term birth is related to unique inflammatory transcriptome profiles at the maternal fetal interface. PeerJ. 2017;5:e3685.

32. Ireland DJ, Nathan EA, Li S, et al. Preclinical evaluation of drugs to block inflammation-driven preterm birth. Innate Immun. 2017;23(1):20-33.

33. Lim R, Barker G, Lappas M. TLR2, TLR3 and TLR5 regulation of pro-inflammatory and pro-labour mediators in human primary myometrial cells. J Reprod Immunol. 2017;122:28-36.

34. Arthur P, Taggart MJ, Zielnik B, Wong S, Mitchell BF. Relationship between gene expression and function of uterotonic systems in the rat during gestation, uterine activation and both term and preterm labour. J Physiol.
2008;586(24):6063-76.

35. Cook JL, Shallow MC, Zaragoza DB, Anderson KI, Olson DM. Mouse placental prostaglandins are associated with uterine activation and the timing of birth. Biol Reprod. 2003;68(2):579-87.

36. Christiaens I, Zaragoza DB, Guilbert L, Robertson SA, Mitchell BF, Olson DM. Inflammatory processes in preterm and term parturition. J Reprod Immunol. 2008;79(1):50-7.

37. Nadeau-Vallee M, Obari D, Quiniou C, et al. A critical role of interleukin-1 in preterm labor. Cytokine Growth Factor Rev. 2016;28:37-51.

38. Romero R, Mazor M, Tartakovsky B. Systemic administration of interleukin-1 induces preterm parturition in mice. Am J Obstet Gynecol. 1991;165(4 Pt 1):969-71.

39. Kamath BD, Macguire ER, McClure EM, Goldenberg RL, Jobe AH. Neonatal mortality from respiratory distress syndrome: lessons for low-resource countries. Pediatrics. 2011;127(6):1139-46.

40. Park CW, Park JS, Jun JK, Yoon BH. FGR in the setting of preterm sterile intra-uterine milieu is associated with a decrease in RDS. Pediatr Pulmonol. 2016;51(8):812-9.

41. Kim SY, Choi CW, Jung E, et al. Neonatal Morbidities Associated with Histologic Chorioamnionitis Defined Based on the Site and Extent of Inflammation in Very Low Birth Weight Infants. J Korean Med Sci. 2015;30(10):1476-82.

42. Park CW, Park JS, Jun JK, Yoon BH. Mild to Moderate, but Not Minimal or Severe, Acute Histologic Chorioamnionitis or Intra-Amniotic Inflammation Is Associated with a Decrease in Respiratory Distress Syndrome of Preterm Newborns without Fetal Growth Restriction. Neonatology. 2015;108(2):115-23.

43. Willems MGM, Kemp MW, Fast LA, et al. Pulmonary vascular changes in extremely preterm sheep after intra-amniotic exposure to Ureaplasma parvum and lipopolysaccharide. PLoS One. 2017;12(6):e0180114.

44. Vollsaeter M, Roksund OD, Eide GE, Markestad T, Halvorsen T. Lung function after preterm birth: development from mid-childhood to adulthood. Thorax. 2013;68(8):767-76.

45. Ekici B, Aydinli N, Aydin K, Caliskan M, Eraslan E, Ozmen M. Epilepsy in children with periventricular leukomalacia. Clin Neurol Neurosurg. 2013;115(10):2046-8.

46. Inder TE, Volpe JJ. Mechanisms of perinatal brain injury. Semin Neonatol. 2000;5(1):3-16.

47. Kitanishi R, Matsuda T, Watanabe $\mathrm{S}$, et al. Cerebral ischemia or intrauterine inflammation promotes differentiation of oligodendroglial precursors in preterm ovine fetuses: possible cellular basis for white matter injury. Tohoku J Exp Med. 2014;234(4):299-307.

48. Herzog M, Cerar LK, Srsen TP, Verdenik I, Lucovnik M. Impact of risk factors other than prematurity on periventricular leukomalacia. A population-based matched case control study. Eur J Obstet Gynecol Reprod Biol. 2015;187:57-9.

49. Jung EY, Park KH, Han BR, Cho SH, Yoo HN, Lee J. Amniotic Fluid Infection, Cytokine Levels, and Mortality and Adverse Pulmonary, Intestinal, and Neurologic Outcomes in Infants at 32 Weeks' Gestation or Less. J Korean Med Sci. 2017;32(3):480-7.

50. Paton MCB, McDonald CA, Allison BJ, Fahey MC, Jenkin G, Miller SL. Perinatal Brain Injury As a Consequence of Preterm Birth and Intrauterine Inflammation: Designing Targeted Stem Cell Therapies. Front Neurosci. 2017;11:200.

51. Choi JY, Rha DW, Park ES. The Effects of the Severity of Periventricular Leukomalacia on the Neuropsychological Outcomes of Preterm Children. J Child Neurol. 2016;31(5):603-12.

52. Tann CJ, Nakakeeto M, Willey BA, et al. Perinatal risk factors for neonatal encephalopathy: an unmatched case-control study. Arch Dis Child Fetal Neonatal Ed. 2017.

53. Celik IH, Demirel G, Canpolat FE, Dilmen U. A common problem for neonatal intensive care units: late preterm infants, a prospective study with term controls in a large perinatal center. J Matern Fetal Neonatal Med. 2013;26(5):459-62.

54. Nikiforou M, Kemp MW, van Gorp RH, et al. Selective IL-1alpha exposure 
to the fetal gut, lung, and chorioamnion/skin causes intestinal inflammatory and developmental changes in fetal sheep. Lab Invest. 2016;96(1):6980 .

55. Ducey J, Owen A, Coombs R, Cohen M. Vasculitis as part of the fetal response to acute chorioamnionitis likely plays a role in the development of necrotizing enterocolitis and spontaneous intestinal perforation in premature neonates. Eur J Pediatr Surg. 2015;25(3):284-91.

56. Tare M, Bensley JG, Moss TJ, et al. Exposure to intrauterine inflammation leads to impaired function and altered structure in the preterm heart of fetal sheep. Clin Sci (Lond). 2014;127(9):559-69.

57. Park HW, Choi YS, Kim KS, Kim SN. Chorioamnionitis and Patent Ductus Arteriosus: A Systematic Review and Meta-Analysis. PLoS One. 2015;10(9):e0138114.

58. Behbodi E, Villamor-Martinez E, Degraeuwe PL, Villamor E. Chorioamnionitis appears not to be a Risk Factor for Patent Ductus Arteriosus in Preterm Infants: A Systematic Review and Meta-Analysis. Sci Rep. 2016;6:37967.

59. Nguyen MU, Wallace MJ, Pepe S, Menheniott TR, Moss TJ, Burgner D. Perinatal inflammation: a common factor in the early origins of cardiovascular disease? Clin Sci (Lond). 2015;129(8):769-84.

60. Bariani MV, Correa F, Leishman E, , et al. Resveratrol protects from lipopolysaccharide-induced inflammation in the uterus and prevents experimental preterm birth. Mol Hum Reprod. 2017;23(8):571-81.

61. Facchinetti F, Vergani P, Di Tommaso M, et al. Progestogens for Maintenance Tocolysis in Women With a Short Cervix: A Randomized Controlled Trial. Obstet Gynecol. 2017;130(1):64-70.

62. Brizot ML, Hernandez W, Liao AW, et al. Vaginal progesterone for the prevention of preterm birth in twin gestations: a randomized placebo-controlled double-blind study. Am J Obstet Gynecol. 2015;213(1):82 e1-9.

63. Mold JE, Michaelsson J, Burt TD, et al. Maternal alloantigens promote the development of tolerogenic fetal regulatory $T$ cells in utero. Science. 2008;322(5907):1562-5.

64. La Cava A. Tregs are regulated by cytokines: implications for autoimmunity. Autoimmun Rev. 2008;8(1):83-7.

65. Papayianni A, Serhan CN, Brady HR. Lipoxin A4 and B4 inhibit leukotrienestimulated interactions of human neutrophils and endothelial cells. J Immunol. 1996;156(6):2264-72.

66. Serhan CN, Maddox JF, Petasis NA, et al. Design of lipoxin A4 stable analogs that block transmigration and adhesion of human neutrophils. Biochemistry. 1995;34(44):14609-15.

67. Rinaldi SF, Catalano RD, Wade J, Rossi AG, Norman JE. 15-epi-lipoxin A4 reduces the mortality of prematurely born pups in a mouse model of infection-induced preterm birth. Mol Hum Reprod. 2015;21(4):359-68.

68. Dinarello CA, Simon A, van der Meer JW. Treating inflammation by blocking interleukin-1 in a broad spectrum of diseases. Nat Rev Drug Discov. 2012;11(8):633-52.

69. Girard S, Tremblay L, Lepage M, Sebire G. IL-1 receptor antagonist protects against placental and neurodevelopmental defects induced by maternal inflammation. J Immunol. 2010;184(7):3997-4005.

70. Quiniou C, Sapieha P, Lahaie I, et al. Development of a novel noncompetitive antagonist of IL-1 receptor. J Immunol. 2008;180(10):6977-87.

71. Nadeau-Vallee M, Quiniou C, Palacios J, et al. Novel Noncompetitive IL-1 Receptor-Biased Ligand Prevents Infection- and Inflammation-Induced Preterm Birth. J Immunol. 2015;195(7):3402-15.

72. Di Renzo GC, Roura LC, European Association of Perinatal Medicine-Study Group on Preterm B. Guidelines for the management of spontaneous preterm labor. J Perinat Med. 2006;34(5):359-66.

73. Hydroxyprogesterone caproate did not reduce the rate of recurrent preterm birth in a prospective cohort study. Am J Obstet Gynecol. 2017;216(6):600 e1- e9.

74. Furuya H, Taguchi A, Kawana K, et al. Resveratrol Protects Against Pathological Preterm Birth by Suppression of Macrophage-Mediated Inflammation. Reprod Sci. 2015;22(12):1561-8.

75. Lagouge M, Argmann C, Gerhart-Hines Z, et al. Resveratrol improves mitochondrial function and protects against metabolic disease by activating SIRT1 and PGC-1alpha. Cell. 2006;127(6):1109-22.
76. Shen Z, Ajmo JM, Rogers CQ, et al. Role of SIRT1 in regulation of LPSor two ethanol metabolites-induced TNF-alpha production in cultured macrophage cell lines. Am J Physiol Gastrointest Liver Physiol. 2009;296(5):G1047-53.

77. Lappas M, Mitton A, Lim R, Barker G, Riley C, Permezel M. SIRT1 is a novel regulator of key pathways of human labor. Biol Reprod. 2011;84(1):167-78.

78. Littman DR, Rudensky AY. Th17 and regulatory T cells in mediating and restraining inflammation. Cell. 2010;140(6):845-58. 